\title{
9. Street Users in Drug Policy: On the Underestimated Role of Welfare Institutions
}

Nicolay B. Johansen

\section{Introduction}

A wind of liberalization has been manifest in drug policy for decades, while the political establishment has stubbornly refused to give in with regards to the penal regime. But how would liberalization change the situation for drug users in Norway? In this chapter, I argue that a reform decriminalizing drug use would not alter the major structure of the controlling environment for street users.

In 2018 the Conservative government announced that they had prepared a 'drug-reform', and in late 2019 a committee gave their white paper on how to decriminalize minor drug violations. In 202I, the process again stops short of any significant reform on the political level. Penalization of any association with illegal drugs has been a cornerstone in Norwegian drug policies and one of the most important legal resources for policing for decades, as is broadly the case in the other Nordic countries. In Nordic criminological circles there has been a widespread consensus that a move away from the penal regime is long overdue (Christie \& Bruun 1996; Houborg, Asmussen \& Bjerge 2008; Ólafsdóttir 200I). This chapter argues that criminology has been too focussed on the penal aspects of current drug policy. Expectations for political improvements of a decriminalization reform overlook the fact that it is the welfare state, in all of its institutional forms, that define the conditions of drug users. I make the claim that

How to cite this book chapter:

Johansen, Nicolay B. Street Users in Drug Policy: On the Underestimated Role of Welfare Institutions. In: Retreat or Entrenchment? Drug Policies in the Nordic Countries at a Crossroads, edited by Henrik Tham, 2 I I-237. Stockholm: Stockholm University Press, 202 I. DOI: https://doi.org/IO.I6993 /bbo.i. License: CC BY 4.०. 
the proposition to decriminalize possession of minor amounts of illegal drugs will not alter the situation for street-level drug users. I will not discuss consequences of such a reform on prophylactic activities regarding younger people.

In the next section I present a review of recent changes in drug policy. I open up with a broader view of what drug policy is, and then provide a more precise conception of the welfare state: the state 'takes care' of its citizens. The development of drug-related deaths indicates that the obligation to take care is not taken as literally as in other political areas. A fundamental example is found in the area of knowledge production, which forms the basis of political activities. Whereas the state takes a keen interest in the health of the population at large, the equivalent interest in the health of drug users is conspicuously absent. To make sense of the divide between drug policy and other areas of the welfare state, I highlight an understanding of the welfare state as an 'institution of curtailment'. A brief overview of drug treatment is offered in the last section to exemplify how the welfare state is both a provider and an executioner in contemporary drug policy. This example is based on the experience of a user and also serves as a substitute for the gap left by the research community. The absence of more knowledge about these aspects of drug treatment reveals that the research community is more or less completely absorbed in the prevailing knowledge regime (Campbell \& Pedersen 20I4) defined by the perspectives of the treatment sector. To prepare this argument, however, it is necessary to explain why the term 'drug policies' is sometimes used in plural tense and attend to the shortcomings for understanding this political field.

\section{Theorizing Drug Policies}

The argument presented here does not rely on a specific method, other than putting pieces together in a somewhat unfamiliar way. The target of the argument is understanding - my contribution is not to add data to a hypothesis. Thus, this chapter concerns the sphere of discovery, and not the sphere of justification in Swedbergs terms (Swedberg 20I4; see also Johansen 20I8b). I argue that drug policy needs to be theorized, again with Swedberg, with a more profound understanding of the welfare state. Thus, 
the story to which I refer towards the end of the argument is an example, illuminating the questions and experiences omitted in the research community. It should not be considered as data.

Theorizing implies a focus on concepts and uses of words. In this chapter, I switch between the terms drug policy and drug policies. 'Drug policies' covers a wide range of administrative areas. In the most recent white paper discussing drug policies in its broadest definition, a number of areas are listed (Meld. 30 20 I I): employment, housing, rehabilitation, health care, social benefits and programmes, the treatment sector and legal status (any association with illegal drugs is defined as a criminal offence, and thus suggests drugs are a police matter). All of these areas are part of the field understood as drug policies in administrative circles. What matters here is that drug policies consist of contributions from a wide array of politico-administrative areas.

In Norway, the term for drug policies is 'ruspolitikk'. Ruspolitikk translates directly as 'intoxication policy' (see Edman, Chapter ıo, this volume). Intoxication policy is broader than the concept of 'drug policy'. The term 'intoxicating substances' includes alcohol, whereas 'drugs' in this context are understood as illegal substances. Alcohol policies are, however, left out as a separate field of politics, distinct from 'drug policy'. Policies regarding illegal drugs are separated not merely by a distinct status defined by its illegality, but also by the fact that users of illicit substances are regarded, and treated, differently from other people asking for assistance. Welfare institutions distinguish between people worthy and unworthy of assistance. Drug use is generally a disqualifying attribute (apart from being punishable). Drug users report that they encounter rejections all across the welfare and health sectors (Skyggeutvalget 2020). Accordingly, any regulation does, in principle, relate to users of illicit drugs. Thus, the relevant rules are those that relate to people using drugs and having social and health problems. This is also why it is sometimes referred to as laws and regulations in plural, as drug policies.

Uses of words and concepts reveal underlying ideas. The argument forwarded here challenges some ideas apparently underlying some Nordic criminological circles. Perhaps it is described in too simple terms, but I call it 'the carrot-and-stick paradigm'. 


\section{The Carrot-and-Stick Paradigm}

Christie and Bruun (I996) labelled Norway and Sweden the Nordic 'hawks' of drug policy. Hawks promotes heavier use of punishment, but what is the alternative? Is it treatment? This question is left unresolved by Christie and Bruun. This chapter takes issue with the unclear and contradictory images of the area of politics sometimes referred to as drug policy. I argue that it is necessary to avoid an implicit understanding of drug policy as a binary field defined by punishment and treatment. This is 'the carrot-and-stick paradigm'.

Within the carrot-and-stick paradigm, punishment is seen as the hard measures (sticks) typically advocated by cynics. On the other side, treatment is seen as a soft measure. Both punishment and treatment come in different guises. Punishment is, to some extent, meshed with rehabilitative activities. Through the 20 th century, penal ideologies have shifted back and forth between classical liberal ideals of pure responsibility deterrence on the one hand, and welfarist social engineering in the name of treatment and rehabilitation on the other. 'Treatment' is also a fluid term. It is sometimes referred to as day care in institutional settings with some sort of psychological rehabilitation techniques, sometimes as harm reducing activities such as opioid substitution treatment (OST), and sometimes as welfare in general.

In criminology, the tension between punishment and treatment has been a recurring theme. The founding father of Norwegian sociology of law, Vilhelm Aubert, famously argued that the medical and the penal spheres are inherently incompatible systems of thought and action (Aubert I958). Aubert analyzed the difference between psychiatry and punishment and commented on the contemporary debate over 'treatment ideology' that prevailed in penal administrative circles at the time. Forty years later this work was still seen as a relevant starting point for a meeting of Nordic drug researchers. This meeting gave occasion for a host of different analyses of contemporary drug policy, and fortunately these contributions were published (Ólafsdóttir 200I). This publication harbours different views, but on the whole, it is clear that the participants do not agree on a common understanding of what the field of drug policy is or how it should be interpreted. The 
contributors mostly refer to some sort of bipolarity of punishment and treatment, but the terms are not fixed or agreed upon. Svensson (200I) states that punishment and treatment are two sides of the same coin because the recipient may confuse experiences from the two sides: it was 'difficult to say which is which'. Part of this confusion comes from the fact that the 'treatment ideology' is still in operation within penal institutions (Storgaard 200I). Whereas these and other reflections are well founded, they are still unclear in how drug policy is conceptualized. Träskman (e.g. 200I) said that the burden of punishment had become 'too heavy' and unbalanced, with the weight put on treatment. The implicit expectation of this is that the sides are opposites.

This ambiguity has prevailed. Jepsen (2008: I 5I) commented that the Danes had a long tradition of solving 'social problems via social welfare measures'. In an older review article, Jepsen and Laursen (2002) had discussed the 'ambivalent balance between repression and welfare'. This ambivalence was intensified by the rise of harm reduction (Jepsen 2008: I73). Some years later, Ødegård (20II) would claim that there are inherent contradictions between harm reduction and punishment, and that it ruined the dynamics of drug policy. Houborg and Frank (20I4) and Giertsen (20I2) later observed that the treatment sector is unable to solve or redeem the drug problem, but they leave it at that. In their optics, the problem is that politics is defined by penal law. And by leaving the alternative to punishment open, they implicitly accept the possibility that treatment or welfare may be a benign activity.

The criticism presented here does not rely on the premise that the mentioned authors are at fault. What is argued is that these conceptualizations of drug policy are too narrow, and that what is needed is a more comprehensive view of what drug policy is. In the mentioned works, studies of drug policy are troubled by a tacitly conveyed image of a political field defined by two opposites, defined basically by a positive and a negative pole.

Within the carrot-and-stick framework, the drug-free treatment industry is associated with the benign forces. Treatment in terms of therapeutic efforts to redeem addiction is regarded as a countervailing force opposing the evils of punishment. What is missed in this paradigm is that the treatment sector, the health 
providers, harm reduction activities and welfare organizations in general are interwoven parts of the same political rationality. It is not the police or the penal law (or its agents) that define politics nor coordinate it. The problem is not necessarily found in the realm of penalty, the problem is how the welfare state defines its role in relation to (marginal) citizens. And this, I argue, is part of the reason why decriminalization of minor drug offences will not fundamentally alter the landscape of drug policy.

A closer look at the political developments within the area of drug policy reveals that from an administrative point of view, the broader perspective is taken for granted. This will be shown in the next section, which in turn also portrays the width of welfare activities relevant for drug policy.

\section{Recent Reforms and Political Action Related to Drug Use}

In 20I I the government issued a white paper on drug policies called 'See me! A comprehensive drug policy' (Meld. 30 20II). The title supports the basic premise of this chapter, that drug politics should be seen as the result of activities in many administrative areas. The paper promises to contribute to a 'comprehensive' intoxication policy. For our purposes, it is more relevant that the white paper summarizes former reforms that define developments in the area of drug policy. Their summary highlights the following reforms.

- In 2004 two 'milestones' took place in relation to drug policies. Firstly, a permanent law for fixing rooms was passed in parliament. Secondly, a so-called 'drug reform' (not to be confused with the current reform) altered the structure of drug treatment. The reform was, primarily, a shift of organization, from a municipal model to the state level of government. It also gave drug users in need of care and treatment 'patient rights' on par with ordinary citizens in the general health system.

- In the following years, a programme for dental health was established, targeting people with severe drug-related problems. Dental aid is offered to people enrolled in treatment. 
- In 2007 a white paper on poverty and inequality was published. This paper included attention to people suffering from drug-related problems. In the same year, the first of several 'step-up plans' for the drug area was set in operation. The step-up plans are a monitored fuelling of resources to drug and alcohol relevant activities, mainly on the municipal level. It is important to notice that the 'drug field', on this level, is interwoven in civil society, and as such, is highly dispersed (Hansen et al. 20I9).

- Two major reforms concerning the entire construction of the welfare state were also implemented in this decade. A reform of social services ('NAV-reformen') fused the sector, from one formerly operated with three separated organizations. The aim of this reform was to coordinate social services more effectively. This reform also emphasized the procedural demands for clients, and thus attached drug users to the general goals (not to say 'visions') of social services: to create a pathway from financial dependency of benefits to autonomy (employment). Clients of social services have a right to an 'individual plan' - a coordinated group of servants from the relevant sectors for the individual (health workers for drug users).

- At the turn of the 'oo's' (2010) more resources were channelled to street-level activities for drug users with serious health problems. New legislation in the area of public health also clarified municipal duties regarding health care and follow-up regarding the specific organization of channelling people into labour.

- At the same time, a 'coordination reform' ('samhandlingsreformen') was introduced in the health sector. This reform was made to improve the coordination of activities delivered in the dispersed reality of welfare and health organizations. It is hard to specify the concrete relevance for drug users, but it is stated that drug users are supposed to be met with 'respect, care and influence concerning the content of services' (both on a general level and with regard to their individual situation). The relevance of this reform is perhaps most 
clearly seen in the current ambition to establish a standardized scheme for treatment ('pakkeforløp').

- Looking forward, the white paper (Meld 30 20I I) emphasizes room for improvement in the 'coordination of assistance' to make the local services 'more accessible', 'improving housing conditions', 'improving possibilities for people with drug related problems to find work', 'assisting people having amassed problematic debt', 'possibilities to develop meaningful leisure activities' and 'non-drug related networks', 'close attention to child care', 'improving dental care' and 'mental assistance', and finally, 'continual follow-up on the system of opioid substitution programs'.

The short review offered above does not reflect all the nuances and width in the political activities mentioned, but it reflects the areas that are considered as relevant for drug policies by the government. However, Meld 30 is written in general and un-committal terms, based on 'law in books' and rarely on 'law in action'. So, it does not reflect the changes in real life chances of drug users. To discuss these reforms as law in action is far beyond realistic in a tiny chapter like this. To illustrate the point though, we could look to the reform that has altered the life chances most profoundly, perhaps ever, in drug policy (but still not mentioned in the list above): the establishment of opiate maintenance treatment in 1998 (known as LAR in Norway).

The story of LAR is a tale of small steps in a landscape of people in dire need of assistance. LAR started out as a reticent offer with strict rules and a heavy control regime. Slowly, the strict rules have been lifted. Step by step, LAR has become more flexible, but the regime is still harsh to the patients that do not fit in perfectly (Skyggeutvalget 2020). Despite all this, almost 8000 patients are enrolled in OST in Norway today, and it is hard to think of any social welfare programme that has improved and saved more lives. The design of LAR, however, is a familiar one. The rules of admission (and exclusion) are designed to promote a lifestyle as conformist as possible, and not to save lives (Johansen 2018a). Thus, LAR is organized in a way that leaves out a large part of the drug using population. 
Since the publication of Meld 30, three more activities have been established. Firstly, a 'step-up plan' was vetoed for the entire field of drug policies, and this was repeated twice. The step-up plans involve the coordinated and detailed distribution of added resources to targeted areas of treatment and municipal organizations. These step-up plans are monitored by evaluation teams.

Secondly, increased attention has been given to reduce the number of deaths from overdoses; several nationwide so-called 'overdose strategies' have been implemented. The most recent of these strategies (Helsedirektoratet 2019) opened for activities that have hitherto been considered in conflict with the overall political strategies to counter drug use (to 'minimize demand and market offers'). Prohibition has been seen as the backbone of drug policies, and reference to these ideals prevented drug testing and other harm reduction activities from being accepted. These references were lifted in 2019, and drug testing, among other things, was included in the overdose strategy. This change in operational doctrines may be interpreted as a sign of changes in the overall political climate.

Thirdly, and most recently, the drug-reform committee gave their report (NOU 20I9: 26). They propose to decriminalize the use and possession of illicit substances. Use and possession are still seen as criminal acts but are freed from penal sanctions. The reaction suggested was to meet with a coordination unit to find a way to assist the user. The committee did not propose any changes in legislation regarding selling and distribution, so the main structure of the legal framework is not challenged. No legal channels for obtaining so-called narcotics are suggested (it is not 'legalized'). Due to the criminal definition of use and possession, the police also maintain their right to frisk people suspected of possessing drugs. As a corollary, they also have the right to confiscate (and destroy) illicit drugs they find. One may imagine that the police will have fewer incentives to pursue such actions, but the legal side of frisking will remain the same. Frisked persons will not be punished for possession and use of illegal substances. In place of a penal sanction, the police will order them to meet a commission, inspired by the famous Portuguese model, to seek advice or help for their assumed problems. The radical part of this 
model is that the reaction will, under no circumstances, be open to sanctions of any kind (no fines, fees or any form of monetary burden) if the drug user fails to turn up at the health commission.

The reform ended in a failure. It did not pass in the parliament. I will not dwell on the reasons for this ending, the aim of the chapter is to consider the possible results from a de facto decriminalization of carrying and use of illegal drugs. The model proposed by the committee was made drastically less radical by the bureaucrats preparing a law for parliament. The ensuing political debate also revealed that conservative arguments still have a strong appeal in public exchanges.

The lesson from this overview is that the welfare state convolutes the lives of street users and that the role of penal law is unclear. The theme of this book is 'changes in Nordic drug policy', and although the penal status remains the same, there have been many changes. Optimism on behalf of lifting the penal domination in this area of politics is emerging, but will the decriminalization announced by the government alter the political landscape?

To answer this, we need to consider penalties in the context of the broader scope of welfare institutions and the welfare state as a rationality for state organization. In the next section I will juxtapose welfare rationality and the handling of drug-related deaths.

\section{Death Rates in the Welfare State: The Case Against the Police}

Public debates on drug users have centred on the high death rates in Norway compared to other European countries. This focus shadows the general misery and 'unhealth' (different forms of sickness) endured by many street users (Johansen \& Myhre 2005 ). Elsewhere, I have argued that closer attention to the health conditions of street users, in particular, would draw a more nuanced picture of suffering from the current political regime, and that it could also serve as a source of information on the human effects of drug policies (Johansen 20I 8a). Still, death rates serve as a crude measurement that will suffice for this brief account.

Norway started to count drug-related deaths in 1977. Since then, more than 7000 people have officially died from overdoses or other related causes. During the I980s, the number of deaths 
increased steadily, but it never exceeded 50 people annually. During the I990s, the numbers doubled more or less every third year: I00 was reached in 1992, 200 in 1995, 300 in 1997 and then numbers peaked at 400 in 2001 . They then dropped again to 250 in 2003 , and since then have oscillated between 250 and 300 (Amundsen 2015a).

In 20I 8, 286 people were reported dead from drug-related causes in Norway (NIPH 20I9b). 'Poisoning' caused 2 ro of these, and $5 \mathrm{I}$ were registered as suicides. In 24 deaths, a combination of mental illness and behavioural anomalies was officially the cause of death, and involved illegal drugs.

Drug-related deaths mirror the pattern of the population injecting illegal substances: $30 \%$ involve women, and the average age of the victim is increasing (it was 44 years old in 2018). But apart from this, little is known about the context of these deaths. From the annual evaluations of the opioid maintenance programme (LAR), it appears that patients in that sort of treatment are effectively insulated from overdoses (Waal et al. 2019). This leaves us with a situation in which drug users who fail to qualify or choose not to partake in that kind of assistance are dramatically more likely to die from drug-related causes. A research project was instigated in 2015 to study overdoses more carefully, but this has yet to produce any results.

How high are these numbers? Drug-related deaths have almost reached the number of deaths related to alcohol 350 in 20I 8 ) and are 2.5 times that of traffic accidents (an area in which Norway have comparatively low figures). Drug-related death tolls in Norway are also high in a European context. EMCDDA produces a list of drug-related deaths annually. Per capita, Norway is among the top nations and has held a steady position for decades.

The high numbers have been a public concern for a long time. Some have challenged the validity of comparisons with reference to the quality of Norwegian reporting systems (Amundsen 20I 5 b), but the numbers nevertheless call for an explanation that is not provided. The numbers have been a challenge for the current political regime.

What makes these numbers challenging is that Norway is a welfare state. The welfare state is expected to protect its citizens. 
High death rates among parts of the population are expected to trigger a protective response, whichever group is most vulnerable, i.e. designated organizations keep track of causes of death among the population. A micromesh system monitors the prevalence of diseases. Elaborate systems register weather phenomena such as flooding. When rivers rise above their limits, rescue services move swiftly and people are evacuated. High death tolls in traffic incidents incurred great efforts to prevent future accidents. The welfare state takes care of the population and takes an active interest in its well-being by monitoring its health in detail. This monitoring uses data from the health sector and research.

This contrasts with state interference in drug-related deaths. It is true that drug research has received much funding, but still, research to study the circumstances of drug-related deaths in more detail has not been prioritized, and the activities promoted to reduce the number of deaths have been remarkably absent and unsuccessful, i.e. the 'overdose strategies' mentioned above.

\section{The Role of State Action}

The emergence of overdose strategies may very well reflect a gradual change in politics. Harm reduction has become more and more important. As mentioned above, in 2019 the time came where the benefits of harm reduction measures were believed to outweigh the importance of 'sending the wrong signal' (Helsedirektoratet 2019).

Implicit in the overdose strategies lies an understanding of the causes of drug-related deaths. Such an understanding is rarely proclaimed explicitly, but implicitly these deaths are attributed to inherent qualities in the drugs themselves and destructive lifestyles. While talk about causes of death is, by necessity, reductionist in nature, it is also worthwhile looking at in terms of the role of state agencies. I want to address the impact on living conditions created by rejections from health and welfare institutions. From the vantage point of the carrot-and-stick paradigm, the first inclination is to look at the police and administration of punishment for an explanation of drug-related deaths. As will be evident below, policing contributes to the total amount of pressure on drug users, but their efforts cannot fully account for the developments. 
Indeed, the numbers of reported cases for drug crimes shows a remarkable co-variation with drug-related deaths. The number of reported drug-related violations increased threefold during the I990s, reaching 45,000 cases in $200 \mathrm{I}$. This number then fell by a third in the subsequent years before increasing steadily again until it reached 50,000 in 20I 3 and 20I4. Since then, the numbers have again dropped by a third (the population has also increased by $\mathrm{I} 5 \%$ in this time period). I will offer three brief comments on these figures before I return to the focus on welfare institutions more broadly.

Firstly, reported crimes are peaking in exactly the same year as the peak of drug-related deaths. The bulk of drug-related crimes consist of possession and use of illicit substances. It is common knowledge that these violations are driven by police initiatives. Thus, these figures reflect police activity.

Secondly, the steep increase in police activity was stopped after the Minister of Justice publicly proclaimed that the police should stop running after 'worn out drug users' in 2003.

Thirdly, a break in the trajectory in 20I 4 also came after a public scolding of the police, this time by the Attorney General.

The increase in police activity during the I990s and subsequent years deserves closer scrutiny than I can offer here. Larsson gives a more detailed presentation of policing strategies in his chapter (Chapter 5, this volume). The fact that the two main breaks in the trajectory of drug-related crimes occur after public reactions from high standing officials is, in itself, something to reflect on. (Does it mean that the police organization did not respond to internal communications, or does it reflect that political signals were mixed and that the police organization was confused about how they were expected to respond?) Nonetheless, it would be harsh to blame active policing for the high numbers of drug-related deaths. Firstly, the police appear, at least partly, to take a more relaxed attitude towards the open drug scenes (Lundeberg \& Mjåland 20I7). Secondly, it is not necessarily so that short prison sentences are on top of the list of problems for high-maintenance drug users (they frequently seem to benefit physically and mentally from time out from the drug scene). Third, and most importantly, it is hard to see how the causal link would be if the police were to be held directly responsible. Drug users hide from 
the police, but they also hide from private guards and the general public. And, most importantly, the numbers of deaths have not responded to the drop in charges by two fifths after 20I4. Thus, the case for blaming the police is not so straightforward.

At the time of the peak of drug-related deaths, harm reduction in what has proven to be the most effective form (OST/LAR, mentioned above) was upgraded and opened up to a broader number of the most worn-down drug users. This fact leads the search for causes of death rates in a new direction. I have argued that politics relevant to the control of drug use should be seen broadly, with the long list of administrative entities borrowed from Meld 30 in mind. Harsh policing does not produce deaths among drug users, but it is possible to identify some indirect relations.

First, harsh policing may reflect a harsher political climate. In this way, policing is merely one expression of politics in other parts of the welfare state. A 'tougher stance' is taken also in the health sector, in social services and in other sources of support. The result is that drug users are rejected more often than before when they ask for assistance.

Secondly, and also a result of the first, the general health of drug users deteriorates as a result of the rejections. When the health is poor, death is a more likely outcome. One general observation is that deaths occur when people hide. They hide from the police, from security guards and from being seen at all. They hide for different but related reasons. Drug users injecting the most lethal substance, opioids, hide because they are ashamed, fearful of unpleasant consequences like being arrested, or to protect themselves against robbery.

It is futile to look for scapegoats. The death tolls of drug users are certainly dramatic, and slowly it seems that the alarm bells also ring in government circles. In the remainder of this chapter, I will address how the welfare state produces marginality on a broader scale than can be attributed to police activities.

\section{Curtailing Welfare for the Unworthy}

The minimal definition of a welfare state is that it provides a net of security for citizens who 'fall' from the security associated with a steady income and stable sources of sustenance (Garland 20I6). 
This provision takes different forms, i.e. financial insurance for the individual. It may also be viewed as proactivity to prevent citizens from falling. The number of traffic accidents and deaths has been reduced by $94 \%$ since I 970, (Skadeforebyggende forum 202I, Statistikkbanken 202I), due to better security in cars, laws making the use of safety belts mandatory and, not least, through massive investments in roads. Inquests are routinely established in the wake of fatal accidents. Similarly, the numbers of deaths caused by cordial diseases has been reduced by $50 \%$ since 2008 (NIPH 20I9a). Hospitals conduct autopsies to learn from as many deaths as the finances allow (Johansen 2020). State organizations monitor the prevalence of illnesses and causes of death closely, and are prepared to react quickly if there are changes in threats to the lives of citizens. Some welfare states also operate with a distinct sort of rationality, Garland (2016) says, and take an active interest in rescuing people's lives and securing their health. The Scandinavian states are clearly within this segment of welfare states, but despite the overdose strategies, a comparative keenness has not been seen in relation to the prevention of deaths among injecting drug users.

The welfare state has received increasing attention in recent years (Barker 20I7; Smith \& Ugelvik 20I7). However, this literature misses important aspects of how the Scandinavian welfare states operate. Much of the criminological presentations operate with underdeveloped conceptualizations, similar to the problems associated with drug policy mentioned in the introduction. Welfare is perceived as provisions of goods and security, and the criticism of the welfare state is that it does not live up to the ideals it purports. The typical form of criticism is to point to certain groups that (evidently) suffer from too little support compared to their needs (Barker 20I7). Whereas this form of criticism is a most needed correction to state activities, it misses a crucial element that the Norwegian sociologist Midré pinpointed in I99I. On the basis of an historical account, he claimed that every form of welfare model is centred on criteria for inclusion and exclusion. The crucial element is that benefits are provided with a threshold set to delineate between the 'worthy and unworthy' recipients of assistance. Simply put, those who did not 'fall' as a result of their own responsibility are worthy. A welfare institution does not merely offer benefit, it also rejects applications. An intrinsic aspect 
of welfare institutions is that they say 'no' to people they consider unworthy of assistance and aid. Based on this analysis, Midré characterized welfare as 'institutions of curtailment' (Loedemel \& Trickey 200I; Midré I99I).

For a good part, the benchmarks defining the worthy and the unworthy are found in laws and other forms of regulations, traceable as sources of law in the legal system. It is common knowledge that judgement about worthiness also relies on informal discretion. Informal discretion is informed by stereotypes circulating in political culture and among professionals. For instance, the importance of police culture for organization output has been a main theme in police research for decades (Granér 2004; Lofthus 2009). Similar analyses of the importance of informal discretion in welfare organizations have not been conducted.

The curtailing function of welfare institutions makes the employees operating on the frontline - the street-level bureaucrats - important. Street-level bureaucrats are gatekeepers for the welfare state, and this is a core activity in the Scandinavian model. Gatekeepers operate all over the welfare sector: emergency hospitals and other specialized health institutions, social welfare organizations, housing agents, treatment organizations, housing institutions etc. The argument here is that these gatekeepers, and not merely the police, are crucial in defining the conditions for drug users. The suggested argument here is that the rate of arrests made by the police is an indicator of gatekeeping all over the welfare spectrum, and not a cause itself.

However, I can only partially substantiate this argument. The most obvious example to illuminate curtailment in the welfare state would be in social services. However, a comprehensive presentation of the research on the role of welfare agencies regarding drug users has not yet been made, although Lundeberg and Mjåland produced a very interesting analysis of the political nexus activated when the open drug scene in Bergen was taken down in 20I5 (Lundeberg \& Mjåland 20I7). Mik-Meyer (20I8) also made a promising cross-sectoral approach focussing on the views of social workers. Similar studies would be needed from the health sector. For now, we must rely on anecdotal evidence from the users (Hart 2000). I have made an attempt at an analysis 
with regard to curtailment in LAR as a harm reduction activity (Johansen 20I8a). However, in want of existing research, I will use anectotal evidence on treatment.

Treatment, I argued in the introduction, is as much a part of drug policies as any other sector within the welfare state. What is interesting in this perspective is how they design their demarcation against the unworthy clients. The example provided here is chosen because it sheds at least some light on the role of frontline workers in an assisting sector for drug users within the setting of a welfare state. I will present the views of an experienced drug user reflecting on his journey through the treatment sector. His views are his alone, but they have been collaborated by at least some other people with similar biographies (in conversations with the author).

\section{Power and Knowledge in the Treatment Sector}

Drug treatment has three distinct branches: OST ('LAR' in Norway), policlinic assistance and institutionalized, sometimes drug-free, treatment (which may also be combined with LAR). This section is about the latter, and the term 'treatment' will refer to institutions offering in-house complete care and some sort of therapeutic regime.

It should be made clear from the start that a substantial number of drug users benefit from treatment programmes (Ravndal \& Vaglum 200I). However, troublingly, there is also little success to report (Giertsen 201 2; Ravndal in Skretting 1997). And as Ravndal and her collaborators pointed out on various occasions, the most striking fact has been how many individuals drop out of treatment (Ravndal \& Vaglum 200I). This fact is underplayed by most research (however, Nygård 202 I points out a new pattern). This is but one indication of the underlying presuppositions of both the research community and administration of drug policy (which is funding the research). If one wanted to find out whether treatment was useful systematically it would require a basis for comparison (something functioning as a control group). A control group would involve people having similar troubles associated with drug use but who are not in treatment programmes. Designs 
of this kind does to my knowledge not exist in Norway, and it reveals that the research community shares outlook with the treatment sector (see also Skyggeutvalget 2020).

It is well known (but significantly not recorded) that some therapeutical schools have been particularly lethal ('therapeutic societies'). There are no estimates on the balance of harms and well-being resulting from the treatment sector. Research mostly tells us how many (few) individuals lead a drug-free lifestyle three and five years later (focussing on the tiny fraction that complete the programmes).

In Norwegian research, there is barely any reference to the possibility that people leave their habit independently of treatment institutions. This blindness is remarkable given that episodes of 'natural recovery' are sometimes reported in the press, it is portrayed in popular culture (e.g. Trainspotting) and, not least, it is commonplace in international research. It is a striking feature of Norwegian drug research that there is no research to be found on how drug addicts actually leave their habits (Bretteville-Jensen 2005 briefly mentions this possibility). Toneatto (20I3) claims that 'natural recovery' is a taboo in current medical discourse because it is an anomaly in the paradigmatic understanding that underpins all treatment. It is the treatment industry that defines drug use as addiction, what addiction is and, accordingly, the research agenda. Research has been focussing on the problem 'what works with treatment'. It has been blind to the possibility that factors other than treatment might be helpful.

Furthermore, success stories from the treatment industry are rarely weighted against the drop-out rate (Brorson et al. 20I3) or harms associated with it (Chatfield 20I4). Dropping out becomes a personal failure, and not a failure on behalf of the treatment programmes. What if the treatment programmes do not primarily satisfy the needs of its users? It could be argued that this is what the drop-out rate actually reveals (Ravndal \& Vaglum 200I). Many drug users do not find treatment relevant for their needs. And given that for them, getting out of the drug habit might be a matter of life and death, this is a profound statement.

To summarize, research has not (systematically) addressed the content of drug treatment programmes and what is going on 
inside the institutions delegated the task of curing drug users. One can only speculate why the research community has not shown attention to this aspect of the drug industry, but no matter why, in this void we may instead listen to a former patient looking back at his experiences. In the next sections I will highlight the reflections made by Jan-Erik Tørres, in a lengthy article in a Norwegian journal, based on his personal experiences in both drug-free treatment and OST-based treatment (Tørres 20I9). He claims that these experiences are neither unique nor rare. Whether this is true would be a task for the research sector to find out.

\section{What We Don't Know: Curtailment in Treatment}

Tørres' comment was written before the committee gave their report, but his main argument goes beyond the mandate of the committee to say that, just as important as aspects of punishment, is the 'punishment' found in the treatment sector.

Patients have an inferior position in treatment institutions, Tørres says. The inner life of treatment institutions is defined by the therapeutic ideology it embraces. But the actual therapy is, to a large extent, meaningless, humiliating or of little use for the inmate. Nevertheless, indulgence in the therapeutic activities is central to the quality of the relationship to staff and the stay at the institution. The responsibility for this relation, however, is placed on the patient, not the institution. Motivation is the keyword, and the patient is expected to show motivation by his/her involvement in the therapeutic activities. No questions are asked about the attitude among personnel and how that influences this 'motivation'. This creates a dynamic circling on the patient's mental involvement. This, in turn, leads to a preoccupation with the patient's state of mind. Absentmindedness is interpreted as part of the 'illness' or as a way to manipulate staff. Institutions are obsessed with 'manipulating' as an expression of non-involvement. Thus, in cases of a suspected infringement of rules, the patient cannot win. He or she is deemed either guilty or manipulative. Revealed dishonesty is not interpreted as an attempt to avoid sanctions (a normal reaction in most contexts) but as evidence of the person's manipulative character. 
Most institutions use some sort of 'social sanctions', Tørres says. By this term he refers broadly to different forms of peer pressure. The group of patients is activated in correcting the behaviour of individuals, putting them in the 'hot chair' or 'love chair'. However, Tørres dryly remarks, it is not love that is conveyed in these situations. Rather, it is a sort of mass psychosis: 'it is shame inflicted in the hope that it will have a positive behavioral effect' (Tørres 20I9). Chatfield (2014) has traced the historical roots of this activity to the brainwashing programmes developed after the Korean War in the I950s. Some patients decide to leave the institutions in the wake of such events.

Tørres goes on to emphasize the punishment found in the treatment sector, often in the guise of treatment. He says that under the label 'environmental therapy' used in day care, restrictions are given on freedom through curfew hours, room searches and possessions, visitations, the control of or prohibition of use of the telephone/the Internet, denial of leisure time (sometimes with the restriction that one must always have company), strict schedules for meals and the daily rhythm, and when to clean the room to name a few.

Despite that, drug use is the defining problem for patients; a zero-tolerance policy is (to a large extent) adopted for possession of such substances. A recent example of this can also be found in Ramms tale of her daughter's journey through the treatment sector (Ramm 20I9). The patient is treated as guilty because of his/her past. Stereotyping comments like 'people like you' are frequent, Tørres implies, in combination with urine tests and room checks. Humiliating practices are commonplace when infractions of 'house rules' are suspected.

Failure to comply with these rules leads to sanctions in the form of withdrawal of privileges and may ultimately also lead to expulsion from the institution. The decisions to sanction breaches of rules frequently leave the patient bewildered about the grounds for the sanction and the process leading up to it. The employees operate with unfettered discretion, both in terms of how to define the foregoing incident and when to apply which rules.

Needless to say, Tørres and other patients observe and remember the discretion, to their disadvantage more often than their favour. By referring to Tørres' reflections, the intention is not to 
indicate that people working in the treatment sector are systematically working against the interests of patients. This is not Tørres' intention either - people working in this sector often see their line of work as meaningful and perform their part with the intention of being of assistance. It is, nevertheless, worthwhile listening to the experiences brought forward by Tørres as they represent a part of the picture - to him, a defining part of the picture. The consequences of the decisions made under the treatment and environmental therapy label may be just as damning and damaging as any legal punishment administered by the police and courts, Tørres says. And the process leading up to them are usually opaque.

This section provided a critical view of the institution-based treatment sector. Many people associated with drug use who have problematic lives seem to benefit from staying at these institutions. But many patients leave, never to return, and some leave with lower self-esteem than they had when they entered. Some leave with scars, and yet others leave with open mental wounds, desperately vulnerable. And some die from an overdose in this phase. Still others learn something they can use in their further attempts to create a better life.

\section{Concluding Remarks}

The image of drug treatment conveyed above indicates that it is woven into the web of small punishments nudging the individual in the direction of a straight lifestyle, which permeates the entire welfare state. Treatment in this perspective is not merely designed to safeguard the interests of the drug users. On the contrary, it appears as if the treatment industry is designed to conform to the control policies more generally - to force drug users to subordinate themselves to a norm of non-use. Thus, drug treatment is not the opposite of repression, it complements it.

Recke, having witnessed the drug scenes in Norway and Denmark at close hand, concludes in similar ways. She comments that treatment and punishment are 'two sides of the same coin' (Recke 20I4). In the same vein, Jøhncke might be correct in assessing that 'the existence and funding of treatment is legitimate less on grounds of what it produces in terms of improvements to drug users' lives, and more as a politically and culturally 
suitable form of organizing the relationship between drug using and non-using sections of the population' (Jøhncke 2010; 2009: I4). It is the welfare rationality that prevails.

I claim that decriminalization would not alter the fundamental dynamics for street-level drug users. In want of data regarding health and welfare institutions, I have provided an overview of the treatment sector. The advantage of this choice was that it directly challenges the carrot-and-stick paradigm. In the end, the overview of research also reveals that the research community has proven incapable of challenging the current knowledge regime in the area of 'ruspolitikk'.

Where are the researchers? The big questions are not asked. However, the patients do ask these questions, it is merely a matter of listening. Berg (2003) did listen in her field study of a treatment institution. The patients Berg met reacted negatively to the 'talking cure' in institutional treatment. I don't want to talk about it, she reported them saying, 'just give us a job' (Berg 2003). The big question is, what thresholds are there for people to enter the labour market and secure an acceptable way of living? The treatment industry cannot help this situation, but it is nevertheless the question that encapsulates all other issues for the patient. Researchers, on the other hand, analyze the effect of treatment.

The research community has been unable to discover and analyze the skewed framing of drug use and its treatment. So far, the criminological literature has not rid itself of the carrot-and-stick paradigm. This chapter attempts to pave the way for a more comprehensive understanding of drug policy. The ambition is to bring the broad variety of administrative sectors, and the welfare state with its rationality, into the mix of drug policies. To do this, it was also necessary to highlight the curtailing character of the welfare state.

The theme of this volume is a changing Nordic drug policy. The question has been, what changes in drug policies should we expect with decriminalization of use and possession of illicit drugs? When Christie and Tham ventured to research the 'heroes of retreat' at the turn of the century (Christie I996; Tham, introduction of this volume) they were too optimistic. No retreat appeared. But, perhaps, had it emerged, the situation today would not have been all too different from what we experience today anyway. 


\section{References}

Amundsen, E. (20 I 5a). Drug-related causes of death: Socioeconomic and demographic characteristics of the deceased. Scandinavian Journal of Public Health, 43, 57 I-579.

Amundsen, E. (2015b). Narkotikautløste dødsfall. Oslo, Sirus, Sirusrapport 2, 20I 5 .

Aubert, V. (I958). Legal justice and mental health. Psychiatry, 2I, IOI-II3.

Barker, V. (20I7). Nordic Nationalism and Penal Order - Walling the Welfare State. London, Routledge.

Berg, E. (2003). Samhandlingens monolog: En studie av interaksjon mellom klienter med innvandrerbakgrunn og ansatte i tiltaksapparatet for rusmiddelmisbrukere. Sirusrapport I/2003. Oslo: SIRUS.

Bretteville-Jensen, A. L. (2005). Økonomiske aspekter ved sprøytemisbrukeres forbruk av rusmidler: En analyse av intervjuer foretatt I993-2004. Sirusrapport. Oslo: SIRUS.

Brorson, H. H., Ajo Arnevik, E., Rand-Hendriksen, K. \& Duckert, F. (2013). Drop-out from addiction treatment: A systematic review of risk factors. Clinical Psychology Review, 33, Iого-IO24.

Campbell, J. L. \& Pedersen O. K. (2014). The National Origins of Policy Ideas: Knowledge Regimes in the United States, France, Germany, and Denmark. Princeton University Press.

Chatfield, M. (20I4). Institutionalized Persuasion: The Technology of Reformation in Straight Incorporated and the Residential Teen Treatment Industry. (No place): CreateSpace Publishing, Barnes \& Noble.

Christie, N. \& Bruun, K. (1996). Den gode fiende. Oslo: Universitetsforlaget.

Christie, N. (I996). Forbudstidens siste dager. In H. Waal \& W. Pedersen (Eds.), Rusmidler og veivalg. Oslo: Cappelen Akademisk Forlag, pp. 82-88.

Garland, D. (2016). The welfare state: A very short introduction. Oxford, UK: Oxford University Press. 
Giertsen, H. (2OI 2). Policy on drugs in Norwegian prisons: Increased control, answers to poverties and looking for a life after release. Nordic Studies on Alcohol and Drugs, 29(6), 589-604.

Granér, R. (2004). Patrullerande polisers yrkeskultur. Lund, Sweden: University of Lund.

Hansen, I. L. S., Tofteng, M., Holst, L. S., Flatval, V. S. \& Bråthen, K. (20I9): Evaluering av opptrappingsplanen for rusfeltet. Tredje statusrapport. Fafo-rapport 33-20I9.

Hart, A. (2000). Hospits central. Oslo, Hart Books.

Helsedirektoratet (2019). Nasjonal overdosestrategi 2019-2022. https://www.regjeringen.no/contentassets/405 ff92co6e 34 a9e93e 92I4 9ad6I6806/20I90320_nasjonal_overdosestrategi_20I9-2022 .pdf.

Houborg, E., Asmussen Frank, V. \& Bjerge, B. (2008). Drug Policy: History, theory and consequences. Århus, Denmark: Århus University Press.

Houborg, E. \& V. A. Frank (20I4). Drug consumption rooms and the role of politics and governance in policy processes. International Journal of Drug Policy 25(5), 972-977.

Jepsen, J. (2008). Danish drug control policy I945-2007. In V. A. Frank, B. Bjerge \& E. Houborg (Eds.), Drug policy: History, theo$r y$, and consequences. Aarhus, Denmark: Aarhus University Press, I 5 I $-\mathrm{I} 8 \mathrm{O}$.

Johansen, N. B. (2018a). Governing Marginality through Welfare. Federal Sentencing Reporter, 3I(I), 90-98. Vera Institute of Justice, University of California Press.

Johansen, N. B. (2018b). Funnel politics: Framing an irreal space. In A. Fili, S. Ø. Jahnsen \& R. Powell (Eds.), Criminal justice research in an era of mass migration. London: Routledge.

Johansen, N. B. (2020). Power/recognition: Counting and the predicament of the permeable biopolitical state. Theoretical criminology 24(2), I 84-20I. https://doi.org/IO.I I 77\% 2FI3624806I 8779402.

Johansen, N. B. \& Myhre, H. (2005). Skadereduksjon i praksis, del I. Oslo: Rusmiddeletaten. 
Jøhncke, S. (2009). Treatmentality and the governing of drug use. Drugs and Alcohol Today, 9(4), I4-I7.

Jøhncke, S. (2010). Behandlingsbegrepet, klar til skrot? Tidsskrift for stofmisbrugsområdet, I6.

Laursen, L. \& Jepsen, J. (2002). Danish drug policy - an ambivalent balance between repression and welfare. The Annals of the American Academy, AAPSS, 582, July 2002.

Lofthus, B. (2009). Police culture in a changing world. Oxford: Oxford University Press.

Lundeberg, I. R. \& Mjåland, K. (2017). Åpne russcener $i$ Bergen etter stengningen av Nygardsparken: En studie av strategi, tiltak og brukererfaringer. Bergen studies in Sociology: University of Bergen, Norway.

Lødemel, I. \& and H. Trickey (Eds.) (200I). An offer you can't refuse: Workfare in international perspective. Bristol, UK: Policy Press.

Meld St. 30 (20II). Se meg! En helhetlig rusmiddelpolitikk, alkohol - narkotika - doping. White paper. Det kongelige helse- og omsorgsdepartement. https:/www.regjeringen.no/no/dokumenter /meld-st-30-20I I 20I2/id68 60I4/.

Midré, G. (I99I). Bot, bedring eller brød? Oslo: Universitetsforlaget. Mik-Meyer, N. (2018). Fagprofessionelles møde med udsatte klienter. København: Hans Reitzel.

NIPH. (20I9a). Dødsfall etter hjerteinfarkt og hjerneslag er dramatisk redusert. https://www.fhi.no/nyheter/20I9/dodsfall-etter-hjertein farkt-og-hjernesl ag-er-dramatisk-redusert-siste-ti-a/.

NIPH. (20I9b). Narkotikautløste dødsfall 20I8. Report from Norwegian institute for public health. https://www.fhi.no/nettpub /narkotikainorge/konsekvenser-av-narkotika bruk/narkotikautloste -dodsfall-i-norge-i-20 $8 /$.

NOU 2019: 26. Fra straff til hjelp. Helse- og omsorgsdepartementet og Justis- og beredskapsdepartementet. https://www.regjeringen.no /contentassets/dfae684e627f 4 df 29 c8003 5 2bfc4d768/nou-20I9-26 -rusreform---fra-straff-til-hjelp.pdf. 
Nygård, M. (202I). «Fordi ..altså man .. man blir veldig påvirka» Om behandling, laering og indoktrinering $i$ norsk rusbehandling. Masters thesis, VID vitenskapelige høgskole, faculty of social studies.

Ólafsdóttir, H. (Ed.) (200I). Skyldig eller sjuk? Om valet av påföljd för narkotikabruk. NAD-publikation 40. Nordic Centre for Alcohol and Drug Research, Helsinki.

Ramm, A. (2019). Jeg skal passe på deg. Oslo: Gyldendal forlag.

Ravndal, E. \& Vaglum, P. (200I). Bruk av behandlingstiltak blant stoffmisbrukere over en 5-årsperiode. Nordisk alkohol- \& narkotikatidsskrift, I 8(2), I 53-I6I.

Recke, L. (20I4). Kriminell eller syk. Rus og Samfunn, 4/20I4. Skadeforebyggende forum (202I). Trygg i trafikken. https://www .skafor.org/fokusomrader/trafikk/.

Skretting, A. (1997). Evaluering av metadon-prosjektet i Oslo del I: Etablering, inntak av pasienter og forholdet til øvrige behandlingstiltak. Report 4/97. Oslo: Statens institutt for alkohol-og narkotikaforskning.

Skyggeutvalget (2020). Rusfeltet må granskes! The Shadow Council. Unpublished report. https://skyggeutvalget.files.wordpress.com /202I/OI/skyggeutvalget-rapport.pdf.

Smith, P. S. \& T. Ugelvik (Eds.) (20I7). Scandinavian penal history, culture and prison practice: Embraced by the welfare state? London: Palgrave Macmillan.

Statistikkbanken (202I). Trafikkulykker med personskade. Web resource: I 2043: Personer drept eller hardt skadd i veitrafikkulykker I946 - 2020. https://www.ssb.no/statbank/table/I 2043/.

Storgaard, A. (200I). Behandling og kontrol overfor kriminelle stofmisbrugere i Danmark. In H. Ólafsdóttir (Ed.), Skyldig eller sjuk? NAD-publikation 40, pp. I 5-30. Helsingfors: Nordiska nämnden för alkohol- och drogforskning. Helsingfors, Hakapaino Oy.

Svensson, K. (200I). Straff och behandling, två delar av samma helhet. In H. Ólafsdóttir (Ed.), Skyldig eller sjuk? NAD-publikation 40, pp. I83-190. Helsingfors: Nordiska nämnden för alkohol- och drogforskning. Helsingfors, Hakapaino Oy. 
Swedberg, R. (20I4). The Art of Social Theory. Princeton: Princeton University Press.

Toneatto, T. (20I3). Natural recovery. Principles of addiction. Vol I. Elsevier, Academic press.

Träskman, P. O. (200I). Kontroll och behandling av personer som brukar narkotika i Sverige. In H. Ólafsdóttir (Ed.), Skyldig eller sjuk? NAD-publikation 40, pp. 79-I06. Helsingfors: Nordiska nämnden för alkohol- och drogforskning. Helsingfors, Hakapaino Oy.

Tørres, J-E. (20I9). Straff forsvinner ikke med rusreformen. Sykepleien: https://sykepleien.no/meninger/innspill/20I9/o2/straff -forsvinner-ikke med-rusreformen.

Waal, H., Bussesund, K., Clausen, T., Haaseth, A., Lillevold, P. \& Skeie, I. (20I9). Statusrapport 20I8 - LAR i rusreformenes tid. Senter for rus- og avhengighetsforskning, SERAF.

Ødegård, E. (20II). En historikk over norsk narkotikapolitikk og politikkens meningsforankring. Oslo: SIRUS. 